\title{
Geostatistical Assessment of Groundwater Quality from coastal aquifers of Igbokoda, Southwestern Nigeria
}

\author{
Talabi Abel O. \\ Department of Geology, Ekiti State University, Ado-Ekiti, Nigeria
}

\begin{abstract}
Saltwater intrusion is a threat to groundwater quality in most coastal environment of the world. Groundwater quality assessment of Igbokoda coastal area, southwestern Nigeria have been undertaken using geostatistical techniques. Groundwater in the area has overall water quality index of 303, EC of 67$2,440 \mu \mathrm{S} / \mathrm{cm}$ and relatively high hydrochemical concentrations in $\mathrm{mg} / \mathrm{L}$ of $\mathrm{Na}$ (3 .56-624.14), $\mathrm{Zn}(0.05-0.85), \mathrm{Fe}$ (0.01-13.74), $\mathrm{Mn}$ (0.00-1.00) and $\mathrm{Cl}$ (72-2592). Furthermore, six factors, accounting for $77.09 \%$ of the total variance were identified. Factor $1\left(\mathrm{Na}^{+}, \mathrm{K}^{+}, \mathrm{Cl}, \mathrm{EC}\right.$ and $\left.\mathrm{TDS}\right)$, factor $2\left(\mathrm{Mg}^{2+}\right.$ and $\left.\mathrm{SO}_{4}{ }^{2-}\right)$, factor $3\left(\mathrm{Fe}^{2+}\right.$ and $\left.\mathrm{Mn}^{4+}\right)$, factor $4\left(\mathrm{Ca}^{2+}\right.$ and $\left.\mathrm{TH}\right)$, factor $5\left(\mathrm{HCO}_{3}^{-}\right.$and $\left.\mathrm{Cu}^{2+}\right)$ and factor $6\left(\mathrm{NO}_{3}^{-}\right.$and $\left.\mathrm{Zn}^{2+}\right)$. Factors 1,2 and 3 represent ions with dominant hydrochemical concentrations and constitute the main geogenic solute input to the groundwater of the area while factors 4, 5 and 6 are indicators of anthropogenic interference. Piper diagram revealed largely $\mathrm{Na}-(\mathrm{K})-\mathrm{Cl}-\mathrm{SO}_{4}$ water type as brackish water and minor occurrence of $\mathrm{Ca}-(\mathrm{Mg})-\mathrm{HCO}_{3}$ water type as freshwater. Finally, this study revealed the usefulness of geostatistical methods in the hydrochemical data interpretation indicating geogenic and anthropogenic solute input sources into the deteriorating poor groundwater quality in the study area.
\end{abstract}

Keywords: Coastal aquifers, Geostatistical techniques, Saltwater intrusion, Hydrochemical, Water quality index.

\section{Introduction}

Nigeria coastlines are located mainly within the Niger Delta and Dahomey sedimentary basins. These sedimentary basins are made up of massive porous sand and gravel pumping multiple aquifers system [1]. The coastal environment is subject to continuous changes arising from natural and human induced activities. Igbokoda coastal zone (study area) is located within Dahomey sedimentary basin, a coastal zone endowed with abundant important raw materials including the high quality silica sand that is used in glass sheet production, crude oil that constitute the main source of revenue for Nigeria as well as large deposit of untapped bitumen. The coastal zone has one of the largest fish terminals in Nigeria in addition to oil palm production, ogogoro/alcohol distillery and palm wine tapping industries. Based on the above, in the study area, most especially at Igbokoda town that serves as an entree Porte to other towns and villages in the zone, has witnessed rapid growth in population. The area is proned to contamination in view of the shallow nature of the aquifers and increased human activities arising from rapid growth in population apart from threat from saltwater intrusion consequent of recent rapid/erractic climate change. However, recharge into the aquifers of the area is guaranteed in view of the annual rainfall of more than $1500 \mathrm{~mm}$ and other favourable climatic conditions. Thus many hand dug wells/boreholes exist in the area leading to high rate of groundwater abstraction which may pose a serious pressure on groundwater resources if unchecked.

Groundwater is generally free from contamination and is usually preferred to surface water, which is mostly contaminated by anthropogenic activities. However, in some cases, the quality of groundwater can deteriorate to such intolerable levels that interventions are needed prior to usage. Several factors work together to influence groundwater hydrochemistry and determine its suitability for most purposes. Principal among these factors is water-rock interactions that are responsible for most geogenic input of ions into the groundwater system. Mineral weathering processes contribute significantly to the hydrochemistries of surface and groundwater reservoirs throughout the world and have been the subject of most hydrochemical analysis in the literature [2], [3] and [4]. The degree to which rock/mineral weathering influences groundwater hydrochemistry is dependent on several factors including the residence time of groundwater in the host rock, the ambient temperature and $\mathrm{pH}$ among others. Where the residence time is high, the interaction between the rocks and water endures for a long time, leading to a greater degree of interaction which leaches ions into groundwater. Apart from geogenic input of ions into groundwater, anthropogenic input of ions into groundwater are also possible in view of increased human activities including excessive application of fertilizer, unsanitary conditions, rapid urbanization, overexploitation and improper waste disposal [5]. According to [6], 80\% of all the diseases in human being are water-borne. Once groundwater is polluted, its quality cannot be restored by stopping the pollutants from the source. It therefore becomes imperative to regularly monitor the quality of groundwater and to device means to protect it. More exacerbating in the study area is the indiscriminate discharge of wastes and 
industrial effluent directly into the sea or creek without considering the effects of these wastes on the coastal shallow aquifers and aquatic lives.

The multivariate statistical methods have found application in facilitating the understanding of the processes influencing the quality of water in basins apart from its ability to rank the various processes influencing groundwater hydrochemistry in order of importance/significance [7]. One of the most widely used multivariate statistical methods in water quality studies is factor analysis which is a data dimension reduction technique being used to assist in the solution of many problems in earth sciences and other fields. Factor analysis reduces a large number of data of so many variables into a smaller number of uncorrelated factors which are easier to handle and interpret. It is used to uncover the latent structure in the dataset of a set of hydrochemical variables $(8]$.

Based on the foregoing discussions and the fact that Igbokoda coastal aquifers are vulnerable to contamination in view of their shallow nature and high porosity and permeability, this research is focused on the quality assessment of Igbokoda costal groundwater using Water Quality Index (WQI) approach and factor analysis geostatistical method.

\section{Location And Geology}

The study area lies within Dahomey basin (Fig.1) covering mainly Igbokoda and its environ. It is situated between latitude $6^{\circ} 10^{\prime}$ to $6^{\circ} 25^{\prime} \mathrm{N}$ and longitude $4^{\circ} 39^{\prime}$ to $4^{\circ} 53^{\prime} \mathrm{E}$ covering the coastal sand bars that stretch in a NW - SE direction from Okitipupa to the Atlantic ocean.

The area is covered mainly by Quaternary alluvium deposits underlain virtually in all places by the Quaternary coastal plain sands. The coastal plain sands constitute the major shallow hydrogeological units and adequate annual recharge is guaranteed considering the high annual rainfall and other favourable climatic conditions.

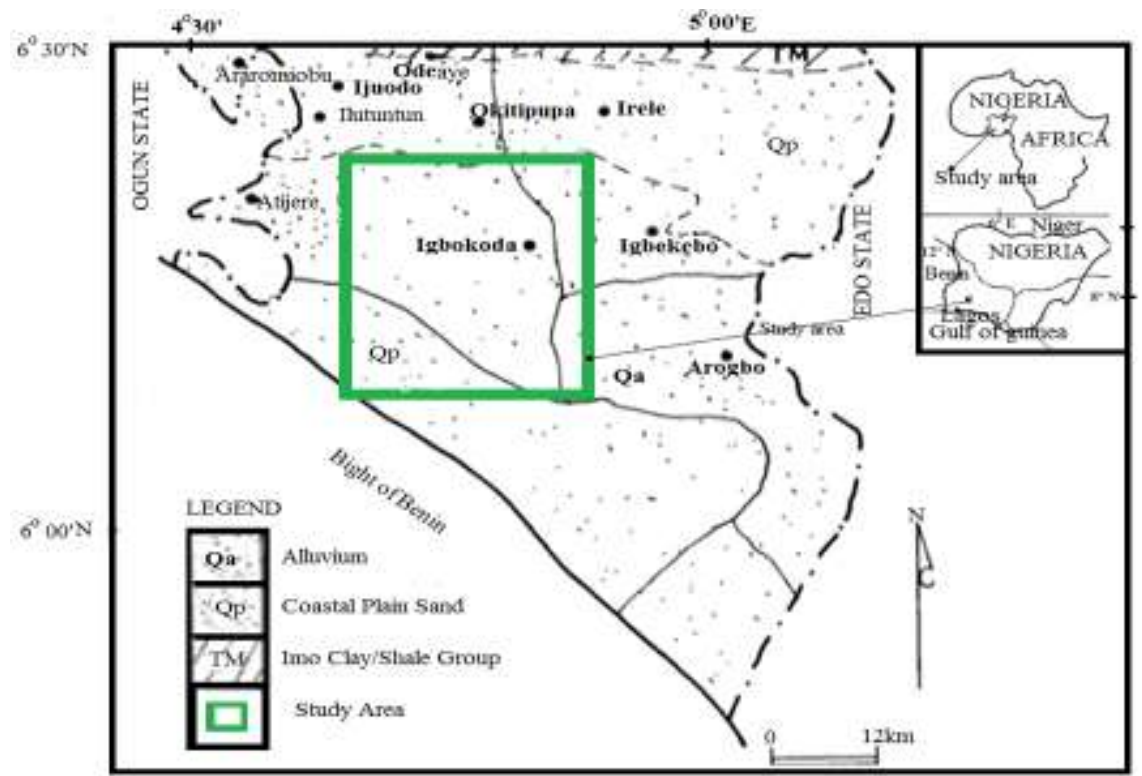

Fig. 1. Geology and location of study area.

\section{Methodology}

Groundwater samples comprising of thirty six shallow well water and three borehole water were collected in February, 2011 using two sets of polyethylene bottles of one liter capacity, for cation and anion analyses. Samples for cations determinations were acidified with concentrated nitric acid on collections to prevent contamination. All the samples were refrigerated before transported to the laboratory for analyses. Cations analysis was carried out using atomic absorption spectrometer while anions determination was by ion chromatographic method. Insitu parameters including temperature, $\mathrm{pH}$ and Electrical conductivity (EC) were determined on the field using a multiparameter portable meter (model Testr-35) while TDS and TH were estimated using multiplication factor of 0.75 and $\mathrm{TH}=(\mathrm{Ca}+\mathrm{Mg}) * 50$ [9] respectively. The ions are expressed in $\mathrm{meq} / \mathrm{L}$.

\subsection{Water Quality Index}

Water quality index (WQI) is one of the most effective tools to test the healthiness of water. A WQI provides a single number (like a grade) that expresses overall water quality at a certain location and time based 
on several water quality parameters. The objective of an index is to turn the complex water quality data into information that is understandable and useable by the public or to link a parameter's concentration to water quality. WQI is defined as a rating reflecting the composite influence of different water quality parameters. WQI is calculated from the point of view of the suitability of groundwater for human consumption [10], [11] and [12]. The Water Quality Index (WQI) was calculated using the Weighted Arithmetic Index method. The quality rating scale for each parameter $\mathrm{q}_{\mathrm{i}}$ was calculated using this expression;

$$
\mathrm{q}_{\mathrm{i}}=\mathrm{Ci} / \mathrm{Si}
$$

Where $\mathrm{q}_{\mathrm{i}}$ is the quality rating scale, $\mathrm{C}_{\mathrm{i}}$ is the concentration of each parameter and $\mathrm{S}_{\mathrm{i}}$ is corresponding standard of the parameter. In this study, parameters values for [13] were used. Relative weight $\left(\mathrm{W}_{\mathrm{i}}\right)$ was calculated by a value inversely proportional to the recommended standard $(\mathrm{Si})$ of the corresponding parameter:

$\mathrm{Wi}=1 / \mathrm{Si}$

The overall Water Quality Index (WQI) for each physical and chemical parameter was calculated by aggregating the quality rating $\left(\mathrm{q}_{\mathrm{i}}\right)$ with unit weight $\left(\mathrm{W}_{\mathrm{i}}\right)$ linearly;

$$
\mathrm{WQI}=\left(\sum_{n=1}^{i=n} \mathrm{q}_{i} \mathrm{w}_{n}\right)
$$

Where:

$\mathrm{q}_{\mathrm{i}}$ : the quality of the ith parameter,

$\mathrm{w}_{\mathrm{i}}$ : the unit weight of the ith parameter and

$\mathrm{n}$ : the number of the parameter considered.

In most situations, WQI is employed for a specific and intended use of water. In this study the WQI for drinking purposes is considered and permissible WQI for the drinking water is taken as 100. The overall WQI is given as;

$$
\mathrm{WQI}=\frac{\Sigma \mathrm{q}_{\mathrm{i}} \mathrm{w}_{\mathrm{i}}}{\Sigma \mathrm{w}_{\mathrm{i}}}
$$

\subsection{Factor analysis}

Apart from the WQI evaluation of the groundwater of Igbokoda coastal aquifers, the physical and chemical data were further subjected to factor analysis using [14] with the aim of identifying the salient construct responsible for the hydrochemical evolution of groundwater in the study area i.e. simplify the quantitative description of a system by determining the minimum number of new variables necessary to reproduce various attributes of the data. Factor analysis is a multivariate method used for data reduction purposes. Again, the basic idea is to represent a set of variables by a smaller number of variables. In this case they are called factors. These factors can be thought of as underlying constructs that cannot be measured by a single variable [15]. Hydrochemical data obtained from the laboratory analyses were used as variable inputs for factor analysis. A variety of tests of normality have been developed by various statisticians [16]. Testing of hypothesis in statistics involved calculation of p-values based on the assumption that the population distribution is normal. To test for normality in this research, data skewness, kurtosis and normality were calculated using [14]. The hydrochemical data were standardized to produce a normal distribution of all variables [15] which was followed by extraction of the initial factor solutions using the principal component analytical method. Thereafter, factor extraction was done with a minimum acceptable eigen value as 1 [17]. The initial factors were rotated orthogonally (TABLE 1) to obtain terminal factor solutions using Kaiser's varimax scheme (18). This method maximizes the variance of the loadings on the factors and hence adjusts them to be either near \pm 1 or near zero [15]. The factor score coefficients were derived from the factor loadings while factor scores were computed for each sample by a matrix multiplication of the factor score coefficient with the standardized data. The importance/significance of each factor at the sampling location is represented by the value of each factor score. A factor score $>+1$ indicates intense influence by the process while very negative values $(<-1)$ reflect areas virtually unaffected by the process while near - zero scores reflect areas with only moderate effect of the process. Based on these facts, factor scores are categorized in order of importance.

\section{Results And Discussion}

The statistical overview of groundwater hydrochemical data from Igbokoda coastal aquifers are summarized in TABLE 1 while the estimated WQI values are shown in TABLE 2. TABLE 3 indicates the global water quality classification scheme with percentage of samples from the study area in different categories. The results of factor analysis generated from the data with the [14] are illustrated in TABLE 4. The univariate statistical overview of groundwater chemistry data (TABLE 1) revealed positively skewed data with 
the exception of $\mathrm{pH}$ and $\mathrm{Cu}$, an indication that the data is not dominated by outliers and as such, mean values can be satisfactorily used as estimate of central tendency. The data also revealed that mean concentration values of $\mathrm{Fe}^{2+}$ and $\mathrm{Cl}^{-}$are above [6]. Using excess kurtosis as measured by [14], virtually all parameters are leptokurtic except $\mathrm{pH}(-0.02)$ and $\mathrm{Cu}^{2+}(-0.07)$ that are platykurtic [19] signifying close range to normal distribution.

The estimated WQI using the weighted arithmetic index method as presented in TABLE 2 revealed total overall WQI of 303 indicating that the groundwater in the study area fall in 'very poor quality' water category. The high value of WQI obtained was as a result of the high concentration of iron, manganese and chloride in the groundwater which can be attributed to natural sources such as saltwater intrusion and chemical weathering processes as well as anthropogenic activities taking place in the area.

Result of factor analysis indicated existence of common factors i.e uncovered latent constructs accounting for the observed hydrochemistry in the study area (TABLE 4)

Six Factor Components with Eigenvalues > 1 emerged accounting for observed hydrochemical evolution in the study area. The first factor loading, factor 1 , with $30.77 \%$ variance showed higher loading for $\mathrm{Na}$ (.760), $\mathrm{K}(.864), \mathrm{Cl}(.718), \mathrm{EC}(.882)$ and TDS (.906). Generally, the high loading for TDS, $\mathrm{EC}, \mathrm{Na}^{+}, \mathrm{K}^{+}$and $\mathrm{Cl}^{-}$ signified geogenic ionic solute input into the groundwater system. However, high $\mathrm{Cl}^{-}$concentration in groundwater may indicate pollutions by sewage, industrial waste or saline water intrusion [20]. The high concentration of EC, TDS, $\mathrm{Na}^{+}$and $\mathrm{Cl}^{-}$suggested that the groundwater might have been affected by saltwater intrusion. Also the relatively high positive correlation ( $\mathrm{R}>0.7)$ among the variables $\mathrm{EC}, \mathrm{TDS}, \mathrm{Na}^{+}$and $\mathrm{Cl}^{-}$for factor 1 is a reflection of the communiality of influence on the chemistry of the groundwater in the area. Sodium and chloride occur naturally in water as a result of erosion or salt water intrusion (when saltwater from the ocean seeps into underground water supplies). Sodium is an essential nutrient and adequate levels of sodium are required for good health. However, sodium and chloride have health implication on human apart from the fact that at high concentration chloride could impart taste in water. Too much sodium is a risk factor for hypertension (high blood pressure). Second factor loading of $14.04 \%$ of total variance, represents higher loadings for $\mathrm{Mg}^{2+}(.522)$ and $\mathrm{SO}_{4}^{2-}$ (.472) which gave further credence to saltwater intrusion into the groundwater of the study area. In general, freshwater was dominated by calcium and seawater by magnesium. Elevated levels of $\mathrm{SO}_{4}{ }^{2-}$ in groundwater are injurious to human health causing diarrhea and dehydration. In addition, $\mathrm{SO}_{4}{ }^{2-}$ at high levels can give water a bitter or astringent taste and can have laxative effects. Infants are more sensitive to high level of $\mathrm{SO}_{4}{ }^{2-}$ in groundwater resulting in infant methaemoglobinaemia (blue-baby syndrome) [21]. The third factor includes higher loadings for $\mathrm{Fe}^{2+}(.898)$ and $\mathrm{Mn}^{4+}(.872)$ at $11.11 \%$ of the total variance. $\mathrm{Fe}^{2+}$ and $\mathrm{Mn}^{4+}$ in groundwater could arise from weathering of $\mathrm{Fe}$ and Mn bearing minerals and rocks in the course of groundwater migration. Industrial effluent, acid- mine drainage, sewage and landfill leachate may also contribute $\mathrm{Fe}$ and $\mathrm{Mn}$ to local groundwater [22]. Leaching through the overlying lateritic sand can increase the iron content of the groundwater and the process is enhanced when the $\mathrm{pH}$ is low [23]. Iron and manganese are not considered a health risk especially at concentrations below the aesthetic objective i.e. $\mathrm{Fe} \leq 0.3$ $\mathrm{mg} / \mathrm{L}$ and $\mathrm{Mn} \leq 0.05 \mathrm{mg} / \mathrm{L}$ [22]. However, $\mathrm{Fe}$ and $\mathrm{Mn}$ at higher concentrations could impart taste, discoloration, deposits and turbidity [5]. The fourth factor have $\mathrm{Ca}^{2+}(.358)$ and $\mathrm{TH}(.355)$ as loading parameters at $9.12 \%$ of the total variance. The loading factors indicated the significant contribution of $\mathrm{Ca}^{2+}$ to total hardness of groundwater in the area.

Table l. Univariate statistical overview of groundwater chemistry data from Igbokoda coastal aquifers

\begin{tabular}{|c|c|c|c|c|c|c|c|c|}
\hline Parameters & Min & Max & Mean & Median & Stclex & S1-exness & Kurtois & WHO (2004) \\
\hline $\mathrm{pH}$ & 6.80 & 9.80 & 8.13 & 8.00 & 0.67 & -3.84 & -0.02 & $6.5-8.5$ \\
\hline $\mathrm{EC}(\mu \mathrm{S} / \mathrm{cm})$ & 67.00 & 2440.00 & 509.41 & 370.00 & 511.31 & 2.31 & 5.89 & 1000 \\
\hline $\operatorname{TDS}(\mathrm{mg} / \mathrm{L})$ & 43.55 & 1586.00 & 331.11 & 240.50 & 332.33 & 2.31 & 5.89 & 500 \\
\hline $\mathrm{TH}(\mathrm{mg} / \mathrm{L})$ & 66.36 & 369.22 & 159.35 & 148.71 & 71.27 & 1.41 & 2.20 & 100 \\
\hline $\mathrm{Ca}^{2}+(\mathrm{mg} / \mathrm{L})$ & 19.21 & 104.32 & 43.33 & 40.41 & 18.62 & 1.25 & 1.62 & 75 \\
\hline $\mathrm{Mg}^{2}+(\mathrm{mg} / \mathrm{L})$ & 3.36 & 75.01 & 12.43 & 9.15 & 14.50 & 3.39 & 15.63 & 50 \\
\hline $\mathrm{Na}^{+}(\mathrm{mg} / \mathrm{L})$ & 3.56 & 624.14 & 104.47 & 73.54 & 131.62 & 2.65 & 8.30 & 200 \\
\hline $\mathrm{K}^{+}(\mathrm{mg} / \mathrm{L})$ & 1.49 & 62.94 & 18.93 & 13.45 & 15.61 & 1.08 & 0.10 & - \\
\hline $\mathrm{Mn}^{2+}(\mathrm{mg} / \mathrm{L})$ & 0.00 & 1.00 & 0.13 & 0.05 & 0.21 & 2.51 & 7.85 & 0.5 \\
\hline $\mathrm{Cu}^{2}+(\mathrm{mg} / \mathrm{L})$ & 0.00 & 0.07 & 0.01 & 0.00 & 0.02 & 1.18 & -0.07 & 1 \\
\hline $\mathrm{Zn}^{2+}(\mathrm{mg} / \mathrm{L})$ & 0.05 & 0.85 & 0.28 & 0.20 & 0.19 & 1.43 & 1.32 & 0.3 \\
\hline $\mathrm{Fe}^{2+}(\mathrm{mg} / \mathrm{L})$ & 0.01 & 13.74 & 2.38 & 1.30 & 3.16 & 2.23 & 5.54 & 0.3 \\
\hline $\mathrm{HCO}_{3}^{-}(\mathrm{mg} / \mathrm{L})$ & 15.25 & 152.50 & 52.01 & 45.75 & 27.71 & 1.81 & 3.92 & - \\
\hline $\mathrm{Cl}^{-}(\mathrm{mg} / \mathrm{L})$ & 72.00 & 2592.00 & 426.36 & 288.00 & 510.60 & 2.79 & 9.61 & 250 \\
\hline $\mathrm{SO}_{4}^{2-}(\mathrm{mg} / \mathrm{L})$ & 0.01 & 5.32 & 1.20 & 0.65 & 1.43 & 1.83 & 3.14 & 250 \\
\hline $\mathrm{NO}_{3}{ }^{-}(\mathrm{mg} / \mathrm{L})$ & 0.01 & 4.39 & 0.53 & 0.20 & 0.84 & 2.92 & 12.34 & 50 \\
\hline
\end{tabular}


Table.2. Computed WQI values for the study area

\begin{tabular}{|c|c|c|c|c|c|}
\hline Parameters & $\mathrm{C}_{j}$ & $\mathrm{~S}_{\mathrm{i}}(\mathrm{SON} 2007)$ & $\mathrm{q}_{\mathrm{i}}$ & $\mathbb{W}_{i}$ & Wigi. \\
\hline $\mathrm{pH}$ & 8.13 & $6.5-8.5$ & 108.4 & 0.133 & 14.453 \\
\hline $\mathrm{EC}(\mu \mathrm{S} / \mathrm{cm})$ & 509.41 & 1000 & 50.941 & 0.001 & 0.051 \\
\hline $\mathrm{TDS}(\mathrm{mg} \mathrm{L})$ & 331.11 & 500 & 66.222 & 0.002 & 0.132 \\
\hline $\mathrm{TH}(\mathrm{mg} \mathrm{L})$ & 159.35 & 200 & 79.675 & 0.005 & 0.398 \\
\hline $\mathrm{Ca}^{2}(\mathrm{mg} / \mathrm{L})$ & 43.33 & 200 & 21.665 & 0.005 & 0.108 \\
\hline $\mathrm{Mg}^{2+}(\mathrm{mg} \mathrm{L})$ & 12.43 & 150 & 8.287 & 0.007 & 0.055 \\
\hline $\mathrm{Na}^{+}(\mathrm{mg} / \mathrm{L})$ & 104.47 & 200 & 52.235 & 0.005 & 0.261 \\
\hline $\mathrm{K}^{+}(\mathrm{mg} \mathrm{L})$ & 18.93 & 100 & 18.93 & 0.01 & 0.189 \\
\hline $\mathrm{Mn}^{4+}(\mathrm{mg} \mathrm{L})$ & 0.13 & 0.2 & 65 & 5 & 325 \\
\hline $\mathrm{Cu}^{2+}(\mathrm{mg} \mathrm{L})$ & 0.01 & 1 & 1 & 1 & 1 \\
\hline $\mathrm{Zn}^{2+}(\mathrm{mg} \mathrm{L})$ & 0.28 & 3 & 9.333 & 0.333 & 3.111 \\
\hline $\mathrm{Fe}^{2+}(\mathrm{mg} \mathrm{L})$ & 2.38 & 0.3 & 793.333 & 3.333 & 2644.444 \\
\hline $\mathrm{SO}_{4}{ }^{2-}(\mathrm{mg} \mathrm{L})$ & 1.2 & 100 & 1.2 & 0.01 & 0.012 \\
\hline $\mathrm{Cl}(\mathrm{mg})$ & 426.36 & 250 & 170.544 & 0.004 & 0.682 \\
\hline $\mathrm{NO}_{3}^{-}(\mathrm{mg} / \mathrm{L})$ & 0.53 & 50 & 1.06 & 0.02 & 0.021 \\
\hline & & & $\Sigma \mathrm{W}_{\mathrm{i} \mathrm{g}_{i} /} \Sigma_{\mathrm{W}}(\mathrm{WQI})$ & & 302.991 \\
\hline
\end{tabular}

Table 3. Standard water quality classification scheme based on WQI value

\begin{tabular}{|c|c|c|}
\hline WQI value & Water quality & Water samples (\%) \\
\hline$<50$ & Excellent & 20.52 \\
\hline $50-100$ & Good water & 15.38 \\
\hline $100-200$ & Poor water & 17.95 \\
\hline $200-300$ & Very poor water & 12.82 \\
\hline$>300$ & Unsuitable for drinking & 33.33 \\
\hline
\end{tabular}

Table 4, Factor loadings and communalities for the groundwater chemistry of the study area

\begin{tabular}{|c|c|c|c|c|c|c|c|}
\hline Parameters & F1 & F2 & F3 & F4 & F5 & F6 & Communalities \\
\hline $\mathrm{Ca}$ & .689 & .380 & -.398 & .358 & .035 & .055 & 910 \\
\hline $\mathbf{M g}$ & .667 & .522 & .289 & .227 & .188 & -.008 & .889 \\
\hline $\mathrm{Na}$ & .760 & -.555 & .103 & -182 & -.045 & .051 & .935 \\
\hline $\mathrm{K}$ & 864 & -.082 & -.029 & .037 & -.247 & .096 & .826 \\
\hline $\mathrm{HCO} 3$ & .201 & -643 & -121 & .002 & .387 & .044 & .620 \\
\hline $\mathrm{Cl}$ & .718 & -.592 & .021 & -149 & -169 & .027 & .919 \\
\hline $\mathrm{SO}_{4}$ & .548 & .472 & -342 & .057 & -.255 & -.256 & .774 \\
\hline $\mathrm{NO3}$ & -.029 & -.022 & -.268 & 393 & .370 & .670 & .814 \\
\hline $\mathrm{Fe}$ & .321 & .126 & .898 & .096 & -.009 & .059 & 939 \\
\hline $\mathrm{Mn}$ & 340 & .222 & 872 & .028 & .123 & .086 & 948 \\
\hline $\mathrm{Cu}$ & .165 & -.182 & .239 & .311 & .372 & -.054 & .356 \\
\hline $\mathbf{Z n}$ & .116 & .356 & .083 & -349 & -.504 & .556 & .832 \\
\hline $\mathrm{pH}$ & .457 & .002 & .083 & 324 & -.162 & -.463 & .562 \\
\hline $\mathrm{EC}$ & .882 & -.364 & -114 & -.127 & -.003 & .057 & .943 \\
\hline Temp & -.231 & -.091 & -.038 & -.255 & .183 & -.128 & .178 \\
\hline $\mathrm{TH}$ & .729 & .433 & -.284 & .355 & .068 & .046 & .932 \\
\hline TDS & 906 & -.383 & -.069 & -.043 & -.027 & .025 & .975 \\
\hline Eigen values & 6.154 & 2.808 & 2.222 & 1.825 & 1.300 & 1.110 & \\
\hline$\%$ of Variance & 30.771 & 14.042 & 11.110 & 9.123 & 6.500 & 5.550 & \\
\hline Cumulative $\%$ & 30.771 & 44.813 & 55.923 & 65.046 & 71.545 & 77.096 & \\
\hline
\end{tabular}

Factor 5 accounts for $6.50 \%$ of the total variance and comprises of $\mathrm{HCO}_{3}{ }^{-}(.387)$ and $\mathrm{Cu}^{2+}(.372)$. The loading parameters indicated contributions to the groundwater both from geogenic and anthropogenic sources. $\mathrm{CO}_{2}$ rich rain water infiltrated the porous subsurface rocks/soils forming weak carbonic acid that triggered water-rock interactions which subsequently affected the groundwater chemistry of the study area. The sixth factor had a moderate loading for $\mathrm{NO}_{3}^{-}(.670)$ and $\mathrm{Zn}^{2+}(.556)$ with $5.55 \%$ of the total variance. Zinc is a trace element that is essential for human health. When people absorb too little zinc they can experience a loss of appetite, decreased sense of taste and smell, slow wound healing and skin sores. Zinc-shortages can even cause 
birth defects [24]. In most groundwater, Zinc post no significant health risk because of its low quantity. However, large concentrations of Zinc, can still cause eminent health problems, such as stomach cramps, skin irritations, vomiting, nausea and anaemia. Very high levels of zinc can damage the pancreas and disturb the protein metabolism, and cause arteriosclerosis [24]. The Zinc is of no significance with respect to groundwater of the study area considering average concetration of $0.28 \mathrm{mg} / \mathrm{L}$ which is lower than [6] approved standard for drinking water. The observed loading factors suggested anhropogenic input into the groundwater of the study area especially with $\mathrm{NO}_{3}{ }^{-}$having loading value of 0.67 .

A plot of eigenvalues versus magnitude (scree-plot) indicated a distinct break between the steepness of the high eigenvalues and the gradual trailing off of the rest of the factors (Fig. 2). In the present study, the extracted 6 factors with eigenvalues $>1$ covered sufficiently the overall data set and accounted for $77.10 \%$ of the total variance. The remaining factors (eigenvalues < 1) accounted for $22.90 \%$ of the total variance. In addition, the high communalities indicated that most of the variance of each variable was explained by the extracted factors

\subsection{Piper diagram}

The hydrochemical evolution of groundwater can be understood by plotting the major cations and anions in the piper trilinear diagram [25]. Piper diagrams aid in determining the chemical reactions taking place in the groundwater as the water moves downgradient.

A Piper diagram is a three-part diagram consisting of two three-component diagrams for anions and cations, and a diamond-shaped field between them. Major cations and anions such as $\mathrm{Ca}^{2+}, \mathrm{Mg}^{2+}, \mathrm{Na}^{+}, \mathrm{K}^{+}$, $\mathrm{HCO}_{3}{ }^{-}, \mathrm{SO}_{4}{ }^{2-}$ and $\mathrm{Cl}^{-}$in meq/l were plotted in Piper's trilinear diagram as the percent of the major constituents. On the piper diagram, the relative concentration of the cations and anions are plotted in the lower triangles, and the resulting two points are extended into the central field to represent the total ion concentration. Two water facies were revealed in this study; the dominant $\mathrm{Na}-(\mathrm{K})-\mathrm{Cl}-\mathrm{SO}_{4}$ brackish water type and minor occurrence of $\mathrm{Ca}-(\mathrm{Mg})-\mathrm{HCO}_{3}$ water type as freshwater. This observed hydochemical facies is a reflection of the wide range and high standard deviation observed in the ionic concentration of $\mathrm{Na}^{+}$and $\mathrm{Cl}^{-}$in the dataset.

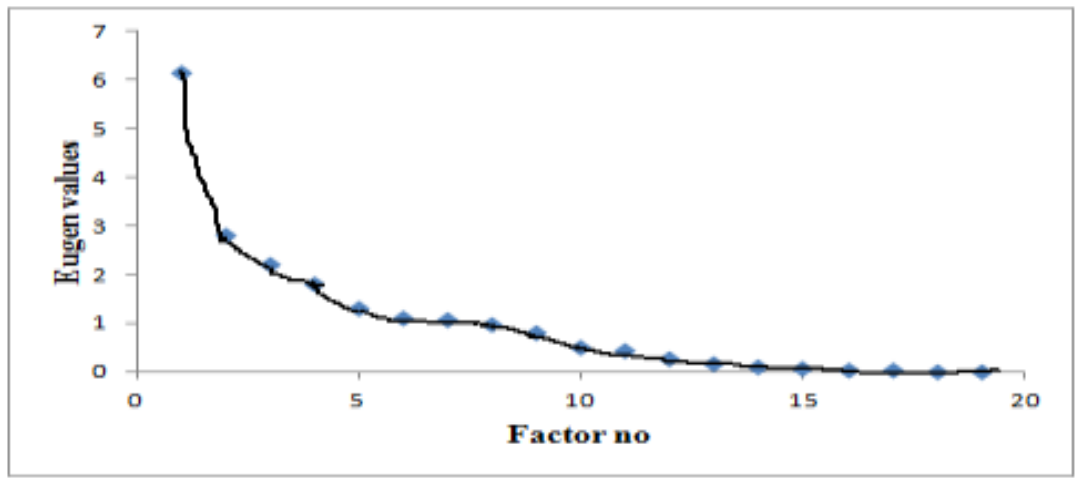

Fig. 2. Scree Plot Test

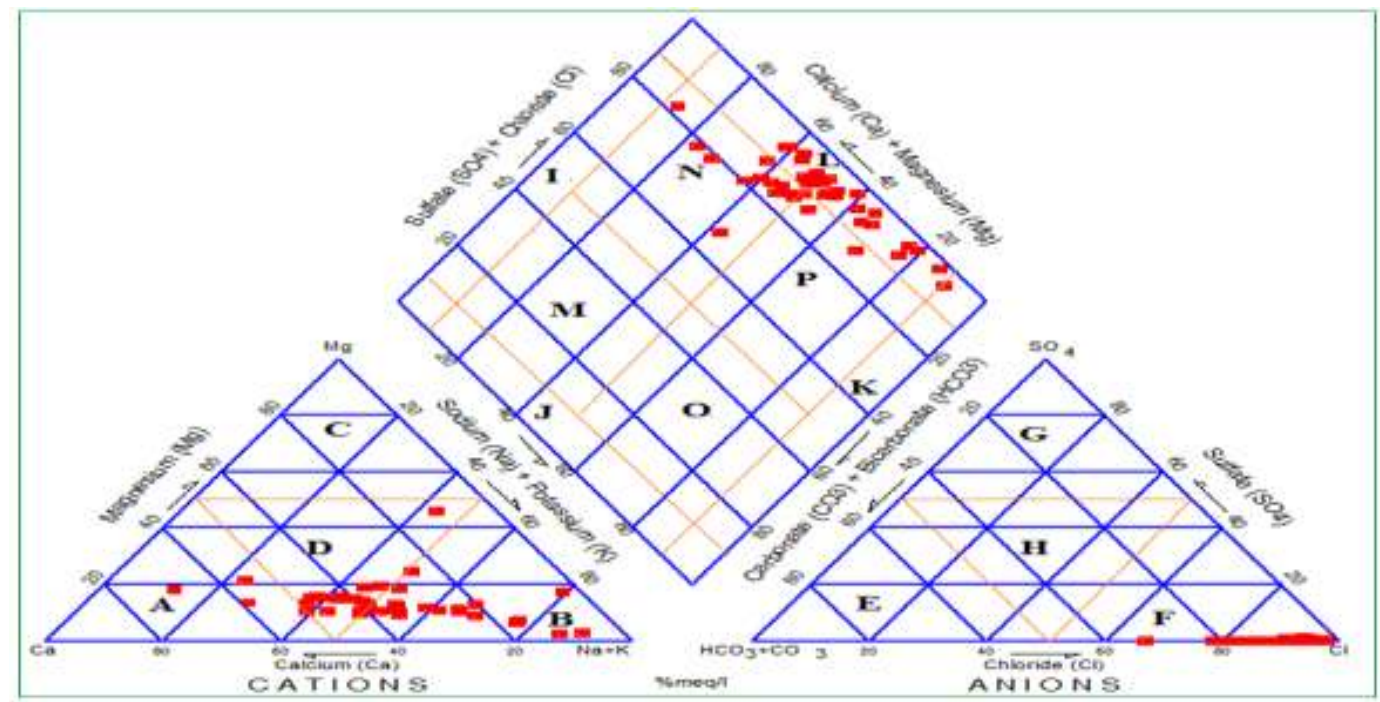

Fig. 3. Water type classification using the Piper Trilinear diagram (Back and Hanshaw, !965) 
$\mathrm{A}=$ Calcium type, $\mathrm{B}=$ Sodium or potassium type $\mathrm{C}=$ Magnesium type, $\mathrm{D}=$ No dominant type .

$\mathrm{E}=$ Bicarbonate type, $\mathrm{F}=$ Chloride type, $\mathrm{G}=$ Sulfate type, $\mathrm{H}=$ No dominant

$\mathrm{I}=\mathrm{Ca}+\mathrm{Mg}$ type, $\mathrm{J}=\mathrm{HCO}_{3}+\mathrm{CO}_{3}$ type, $\mathrm{K}=\mathrm{Na}+\mathrm{K}$ type, $\mathrm{L}=\mathrm{Cl}+\mathrm{SO}_{4}$ type, $\mathrm{M}=\mathrm{Ca}(\mathrm{Mg}) \mathrm{HCO}_{3}$ type, $\mathrm{N}=$ $\mathrm{Ca}(\mathrm{Mg}) \mathrm{Cl} \mathrm{SO} \mathrm{S}_{4}$ type, $\mathrm{O}=\mathrm{Na}(\mathrm{K}) \mathrm{HCO}_{3}$ type, $\mathrm{P}=\mathrm{Na}(\mathrm{K}) \mathrm{Cl}\left(\mathrm{SO}_{4}\right)$ type

\section{Conclusions}

Evaluation of major ions of Igbokoda coastal aquifer indicates that the groundwater quality is not safe for consumption. From estimated WQI (303), it can be concluded that the overall water quality is very poor due to high concentrations of iron, manganese and chloride in the groundwater.

The result of the factor analysis, as applied to the hydrochemical data set in the study area provides an insight into the underlying factors controlling hydrogeochemical processes. The dataset were reduced into six major components representing the different sources of solute input into the groundwater of the area. Major contributors to factors 1,2 and 3 were geogenic phenomenon while those of factors 4 to 6 were of anthropogenic activities. Water characterization using Piper diagram revealed $\mathrm{Na}-(\mathrm{K})-\mathrm{Cl}-\mathrm{SO}_{4}$ brackish water type as dominant and minor occurrence of $\mathrm{Ca}-(\mathrm{Mg})-\mathrm{HCO}_{3}$ water type as freshwater.

Thus this study revealed high levels of $\mathrm{Na}^{+}$and $\mathrm{Cl}^{-}$ions in coastal groundwater of the study area which pointed to the possibility of seawater mixing with the groundwater of the area. The information from the data set provides a base for future hydrochemical work that will help in the planning, protection and decision-making regarding groundwater management in the study area.

\section{References}

[1] H.O. Nwankwoala, Coastal Aquifers of Nigeria: an overview of its management and sustainability considerations. Journal of applied rechnology in environmental sanitation. Vol. 1.No4, 2011, pp371-380.

[2] V. Cloutier, R. Lefebvre, R. Therrien, and M.M. Savard, Multivariate statistical analysis of geochemical data as indicative of the hydrogeochemical evolution of groundwater in a sedimentary rock aquifer system; J. Hydrol.(353), 2008, $294-313$.

[3] S.M. Yidana, Management of groundwater for productive uses in the Afram Plains area, Ghana; PhD dissertation, Montclair State University, Montclair, New Jersey, USA. 2008.

[4] B. Banoeng-Yakubo, S.M. Yidana, and E. Nti, An evaluation of the genesis and suitability of groundwater for irrigation in the Volta region, Ghana; Environ. Geol. 57, 2009, 1005-1010.

[5] A.N. Amadi, Effects of urbanization on groundwater quality: A case study of Port-Harcourt, Southern Nigeria. Natural and Applied Sciences Journal, 11(2), 2010, $143-152$.

[6] World Health Organization (WHO), "Guidelines for Drinking Water Quality", Vol.1, 2004, Recommendations (3rd edn). WHO, Geneva.

[7] S.M. Yidana, B. Banoeng-Yakubo, and P.A. Sakyi, Identifying key processes in the hydrochemistry of a basin through the combined use of factor and regression models. J. Earth Syst. Sci. 121, No. 2, 2012, pp. 491-507

[8] S.M. Yidana, D. Ophori, and B. Banoeng-Yakubo, A multivariate statistical analysis of surface water chemistry - the Ankobra Basin, Ghana; Environ. Manag. 86, 2008a, 80-87.

[9] I.I.M. Raghunath, Groundwater. Second edition; Wiley Eastern Ltd, New Delhi, India, 1987.

[10] P.C. Mishra, and R.K. Patel, Study of the pollution load in the drinking water of Rairangpur, a small tribal dominated town of North Orissa. Indian J Environ Ecoplan. Vol. 5(2), 2001, pp. 293-298.

[11] J.W. Njenga, Comparative studies of water chemistry of four tropical lakes in Kenya and India. Asian J. Water, Environ. Pollu., Vol.1, 2004, 87-97.

[12] A.N. Amadi, P.I. Olasehinde, and J. Yisa, Characterization of Groundwater Chemistry in the Coastal plain-sand Aquifer of Owerri using Factor Analysis. Int. J. Phys. Sci., 5(8), 2010, 1306-1314.

[13] Nigerian Standard for Drinking Water Quality, NSDWQ. Published by Nigerian Industrial Standard. 554, 2007,1 -14.

[14] Statistical Package for the Social Sciences SPSS-16. SPSS Inc., Chicago, USA, 2009.

[15] B.F.J. Manly, Multivariate Statistical Methods: A primer, Third edition,Chapman and Hall, 2005.

[16] J.C. Davis, Statistics and data analysis in geology. John Wiley and Sons, Inc., New York 1973, 550pp.

[17] H.H. Harman, Modern factor analysis. University of Chicago Press, 1960.

[18] H.F. Kaiser, The varimax criterion for analytic rotation in factor analysis. Psychometrika 23, 1958, 187-200.

[19] K.P. Balanda, and H.L. MacGillivray, "Kurtosis: A Critical Review".The American Statistician 42(2) 1988, pp 111-119.

[20] J. Bertram, and R. Balance, Water quality monitoring: A practical guide to the design and implementation of freshwater quality studies and monitoring programmes. $1^{\text {st }}$ Edn. Taylor and Francis, USA, 1998, 400p.

[21] M. McCasland, N. M. Trautmann, R.J. Robert, and K.S Porter, Nitrate: Health effects in drinking water, http://psep.cce.cornell.edu/facts-slides-self/facts/nit-heef-grw85.aspx. 2007.

[22] Water Stewardship Information Series, Iron and manganese in groundwater. www.env.gov.bc.ca/.../groundwater/.../fe_mg(020715)_fin2.

[23] A.N. Amadi, P.I. Olasehinde, J. Yisa, E.A Okosun, H.O. Nwankwoala, and Y.B. Alkali, Geostatistical Assessment of Groundwater Quality from Coastal Aquifers of Eastern Niger Delta, Nigeria. Scientific and Academic Publishing. Geosciences, 2(3), 2012, 51-59.

[24] Zinc (Zn)- Chemical properties, Health and Environmental effects, www.lenntech.com

[25] A.M. Piper, "A graphic procedure in the geochemical interpretation of water analyses". Transactions American Geophysical Union, 25,1944, 914-928. 